\title{
THE RESEARCHES OF EFFECTIVENESS OF ROAD RESTRAINT SYSTEMS
}

\section{BADANIA SKUTECZNOŚCI DROGOWYCH SYSTEMÓW ZABEZPIECZAJĄCYCH}

\author{
Waclaw Borkowski ${ }^{1}$, Zdzisław Hryciów ${ }^{2}$, Piotr Rybak ${ }^{3}$, Józef Wysocki $^{4}$ \\ (1-4) Military University of Technology \\ ul. Kaliskiego 2., 00-908 Warszawa, Poland \\ E-mails: (1)wborkowski@wat.edu.pl, (2) zhryciow@wat.edu.pl, (3)prybak@wat.edu.pl, \\ (4)jwysocki@wat.edu.pl
}

Abstract: The work describes model and experimental tests on the road restraint systems with particular attention to vehicle collisions with a concrete protective barrier. Vehicle and protective barrier crash tests include the experiment results in three basic fields: intensity of influence of the collision effects on vehicle passengers, collision impact on a vehicle and the road restraint system. It presents a test track concept as well as criteria for performing and evaluating the crash tests with a passenger vehicle and a safety barrier. The experimental tests were performed according to the test methodology recommended by the standard [2]. Examples of model test results were compared with experimental test results obtained on the test track.

Keywords: safety barrier, test track, model tests, experimental verification

Streszczenie: W pracy opisano badania modelowe $i$ eksperymentalne drogowych systemów zabezpieczajacych ze szczególnym uwzględnieniem zderzeń pojazdu, ze sztywna bariera zabezpieczajacca. Badania zderzeniowe pojazdu z bariera ochronna obejmuja wyniki eksperymentu $w$ trzech podstawowych obszarach: intensywność oddziaływania skutków zderzenia na osoby znajdujace się $w$ pojeździe, skutki oddziaływania zderzenia na pojazd oraz odkształcenie drogowego sytemu zabezpieczajacego. Przedstawiono koncepcje toru badawczego oraz kryteria przeprowadzenia $i$ oceny próby zderzeniowej samochodu osobowego $z$ betonowa bariera zabezpieczająca. Badania eksperymentalne zrealizowano zgodnie z metodyka badań zalecana przez normę [2]. Przykładowe wyniki badań modelowych porównano z wynikami badań eksperymentalnymi uzyskanymi na poligonowym torze badawczym.

Stowa kluczowe: bariera zabezpieczajaca, tor badawczy, badania modelowe, weryfikacja eksperymentalna 


\section{Introduction}

The Road Restraint Systems (RRS) are used to protect special places on the road that make dangerous zones and areas. The EU member countries apply national standards $[1,2,3,4]$ that make the equivalents of the EU standards within that scope. Safe road requires placing, on some sections, the equipment and structures that will provide safe use for pedestrians and vehicles. Variety of road limiting systems has one basic purpose in any circumstances: to provide the users with maximum safety. Generally, RRS are divided into two subsystems: pedestrian restrain and vehicle restrain. The pedestrian restrain subsystem marks out safe roads for pedestrian traffic. The vehicle restrain subsystem is installed on the road (along the road or on its middle strip which divides the roads). It provides safe directing and braking a vehicle which goes in a wrong direction (providing the passenger safety at the same time), in order to minimize its impact on other road users and prevent further interruption of the road traffic. For that purpose, various types of protection barriers are used (deformable, rigid), collision bags, balustrades for vehicles, stopping roadsides etc.

The use of a particular restraint system, on a particular section of the road, is determined by the following factors: road class and type, road location (e.g. terrain, relief, rivers, channels, water reservoirs and other dangerous locations), infrastructure (high-voltage lines, railways), various structures and buildings etc. However, decision about selection of safety barriers is made by national or local administration bodies.

The work describes model and experimental tests on the road restraint systems with particular attention to vehicle collisions with a concrete safety barrier. Examples of model test results were compared with experimental test results obtained on the test track.

\section{Simulation tests}

\subsection{Numerical model}

The work also presents model and experimental tests of the road safety systems. In order to show the possibilities of using simulation methods for tests and evaluation of effects of a passenger car collision with a barrier, a discrete model of a test object have been developed. It consists of three essential parts: concrete safety barrier system, a vehicle and the ground it moves on. The work carried out by the authors is oriented towards the improvement of concrete barrier operation. Therefore it focuses on a development of a barrier model and defining conditions of mutual 
interaction between individual protective system elements. Due to a complicated and time-consuming process of vehicle model development, the tests were performed with Geo Metro car model developed by the National Crash Analysis Center [6]. The choice was determined by its availability. Development of a complete vehicle model is an extremely time-consuming task and moreover it is difficult due to a limited access to a vehicle technical documentation.

A discrete vehicle model with the barriers are shown on fig. 1. The models tests were performed with a restraint system consisting of 16 segments of total length of $64 \mathrm{~m}$. Each segment made a concrete barrier, height $810 \mathrm{~mm}$, basis width $550 \mathrm{~mm}$ and length: $4000 \mathrm{~mm}$. Each segment included elastic steel connectors with tearing force of $350 \mathrm{kN}$. The connector ends were connected with the elements of couplers that allow to connect individual segments with a possibility of turning individual segments towards each other. In order to define mating conditions between parts of subsystems, the contact between a car and barriers as well as between a car and the road surface were defined.

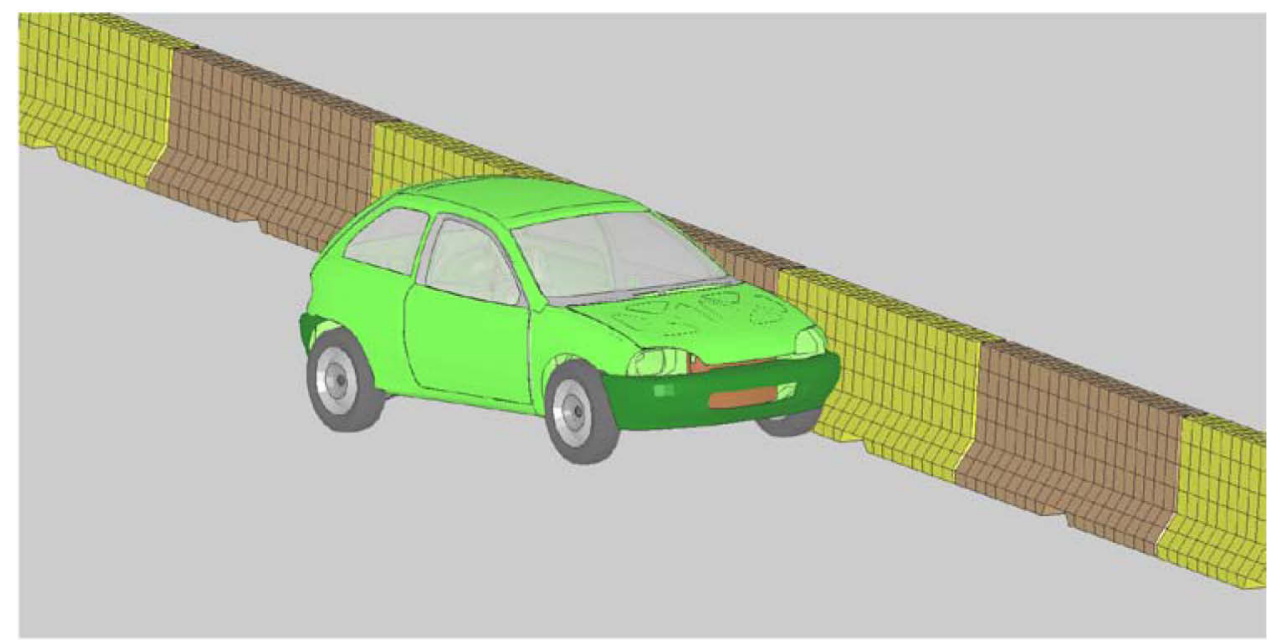

Fig. 1 Model of vehicle

Developed model allowed for evaluation of the concrete safety barrier behaviour during a collision with a passenger car. Geo Metro car, weight of $900 \mathrm{~kg}$, allowed to perform a TB11 crash test (according to EN 1317-2). It is one of the basic tests applied in the road restraint system evaluation process. It allows to define the impact severity level during a crash of a car from the lowest segment, very popular in the European countries. The initial 
speed of the car amounted to $100 \mathrm{~km} / \mathrm{h}$ and it hit the barrier at $20^{\circ}$ angle. The impact point is located on $1 / 3$ of the restraint system length from the vehicle approach direction. During calculations, behaviour of the barrier and the hitting car was registered, including displacement courses, speeds and acceleration of individual elements. At the next stage, they were used to define the barrier working width and impact severity level. The calculations were carried out using LS-DYNA software [7], which applies the finite element method (FEM).

\subsection{Test results}

Fig 2. presents selected phases of collision of a $900 \mathrm{~kg}$ car with a concrete barriers placed at $20^{\circ}$ angle towards the direction of the vehicle motion. Due to a relatively low weight of the car compared to a segment weight (2 340 $\mathrm{kg}$ ) the barrier movement is very little. It was limited just to two segments located next to the point of impact. The car run into the barrier and then the direction of its motion was changed. The car was guided along the barrier wall and at the final stage it was led out at a small angle towards the barrier axis. During the test the car did not exceed the acceptable area indicated by the standard. No significant deformations of the body structure or drive system damage were observed.

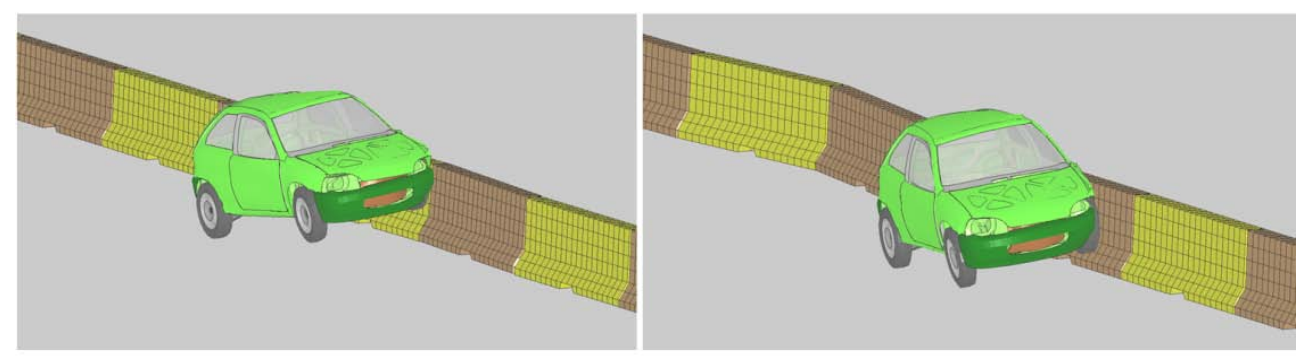

Fig. 2 Phases of collision

Fig. 3. presents a course of longitudinal accelerations for the car centre of gravity. During the impact, the maximum acceleration values amounted to app. 10g. The acceleration severity index has been defined on the basis on that course. For the analysed variant it amounted to 1.3 (impact severity level B). During the test, the maximum barrier segment displacement amounted to $0.33 \mathrm{~m}$, and considering the barrier width of $0.55 \mathrm{~m}$ it indicates that the working width value amounts to $0.88 \mathrm{~m}$ (class W3). 


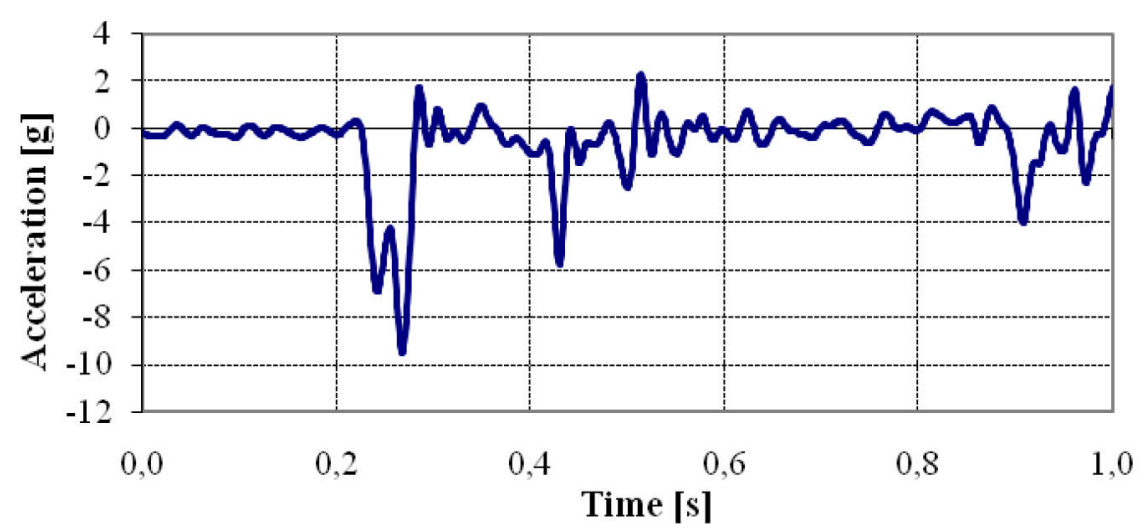

Fig. 3 Longitudinal accelerations for the centre of car mass

\section{Experimental tests}

\subsection{Test methodology}

In case of road restraint systems, the experimental tests are carried out on the test tracks, according to the concept shown on fig. 4. A test track is built on a separated flat paved area and its inclination should not exceed $2.5 \%$. Each test track includes: a manoeuvre area (PM), test vehicle acceleration and driving track (TP), two test areas (OB1, OB2); the first one for the measurement of vehicle reflection area, the second one for the measurement of safety barrier deformations. In order to carry out experimental tests according to the test methodology recommended by the standard [2], each test track has to be equipped with the following assemblies and systems: for a test vehicle acceleration and emergency braking, registration of vehicle motion parameters (acceleration and impact speeds, safety barrier impact angle) and impact effects, visual recording by means of high sensitivity and high recording rate camera (minimum 200 frames per second) and communication system for coordination, notification and warning. Measurement techniques, systems, devices and instrumentation applied in crash tests need to fulfil the requirements defined in the standard[5].

The tests of vehicle and safety barrier collision include the experiment results in three basic areas:

- intensity of influence of the impact on vehicle passengers,

- effects of influence of the impact on a vehicle,

- road restraint system deformation. 


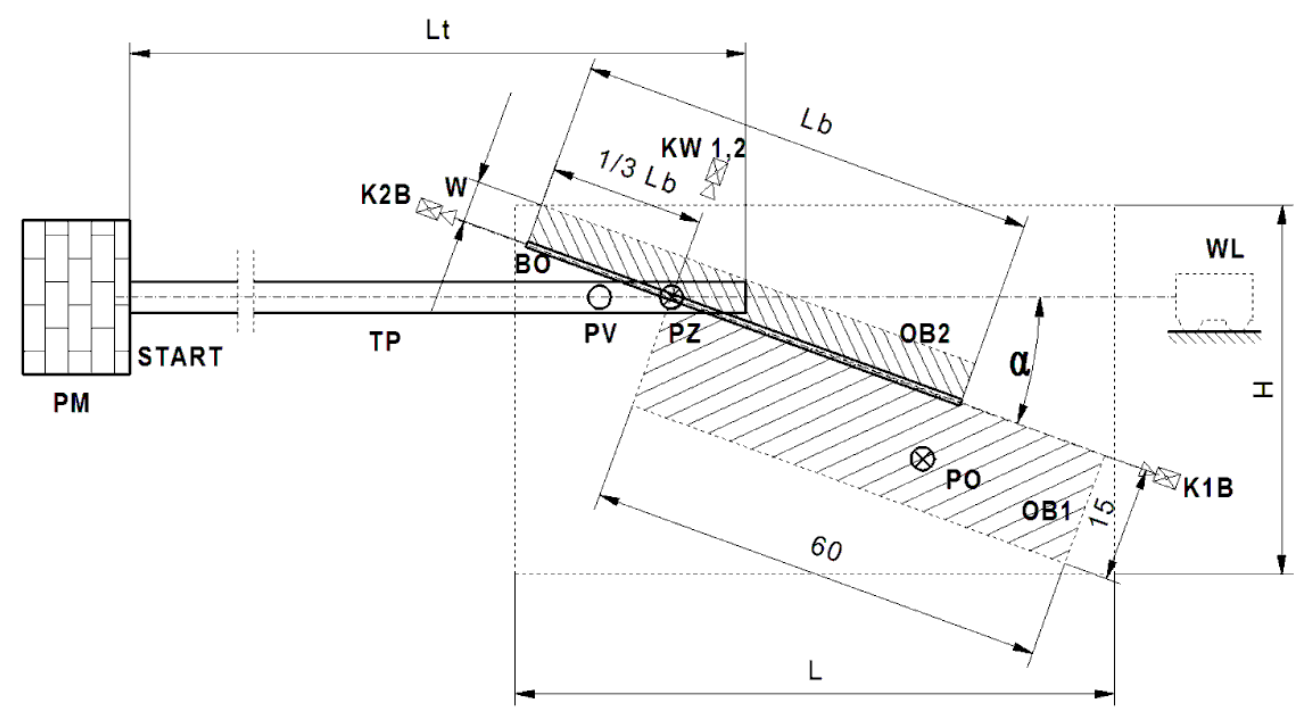

Fig. 4 Test track concept for car crash tests with a rigid or deformable safety barrier

$B O$ - safety barrier, OB1,2 - test areas, TP - measurement track, $P M-$ manoeuvre area, $P Z$ - point of impact, $P V$ - point of speed measurement, $L b$ - barrier length, $L t$ - measurement track length, K1B, K2B - cameras in the barrier axis, KW1,2 - cameras placed on extension arm over, $P Z$, $P O$ - reflection area coordinates for a tested vehicle (according to PNEN 1317-2), W- barrier working width.

The standard [2] proposes 11 crash test types, including 5 for passenger vehicles of complete weights of $900-1500 \mathrm{~kg}$ (TB11, TB21, TB22, TB31, TB32), one for the buses of complete weight amounting to $13000 \mathrm{~kg}$ (TB51) and articulated vehicles (TB81) of complete weight of $38000 \mathrm{~kg}$ and 4 for trucks of complete weights of 10000,16000 and $30000 \mathrm{~kg}$ (TB41, TB42, TB61, TB71), supplemented with car crash test criteria (vehicle weight, speed and impact angle).

Four restrain level groups were assumed:

- low (T1, T2, T3),

- normal (N1, N2),

- higher (H1, H2, H3),

- very high (H4a, H4b).

Bearing in mind the above standards, a particular crash test type or a combination of types have been defined for a set restrain level $(\mathrm{T}, \mathrm{N}$ or $\mathrm{H})$, e.g. TB31 is assumed for N1, but TB81 + TB11 should be assumed for H4b. 
Behaviour of a safety barrier and a test vehicle is evaluated with particular attention paid to the impact effects on vehicle passengers is evaluated in each crash experiment. The following parameters are defined on the basis of time courses of component accelerations (longitudinal, transverse and vertical ones) measured in the centre of car mass:

- theoretical head impact velocity (THIV) $[\mathrm{km} / \mathrm{h}]$;

- post-impact head deceleration (PHD) [g];

- acceleration severity index (ASI).

Mutual relations between THIV, PHD and ASI and their values determine the impact severity levels. Three levels can be differentiated: A, B and C the details are presented in Table 1.

Table 1. Impact severity levels [2]

\begin{tabular}{|c|c|c|c|}
\hline Level & ASI & $\begin{array}{c}\text { THIV } \\
{[\mathbf{k m} / \mathbf{g o d z} .]}\end{array}$ & PHD [g] \\
\hline A & $\leq 1,0$ & $\leq 33$ & $\leq 20$ \\
\hline B & $1,0-1,4$ & $\leq 33$ & $\leq 20$ \\
\hline C & $1,4-1,9$ & $\leq 33$ & $\leq 20$ \\
\hline
\end{tabular}

Experimental test results, obtained on a test track during a car collision with a concrete barrier, make a basis for evaluation of behaviour after impact and measurement of vehicle reflection area and vehicle cabin deformation index (VCDI) and deformation expanse i.e. percentage reduction of its selected internal dimensions.

Two parameters are used in evaluation of the road restraint system deformation: dynamic deflection and working width. In general, eight classes of working width levels W1 to W8 are assumed, where the working width varies $0.6 \geq \mathrm{W} \leq 3.5 \mathrm{~m}$. Detailed are presented in Table 2 .

Table 2. Working width levels [2]

\begin{tabular}{|l|c|c|c|c|c|c|c|c|}
\hline Level & W1 & W2 & W3 & W4 & W5 & W6 & W7 & W8 \\
\hline $\begin{array}{l}\text { Working } \\
\text { width [m] }\end{array}$ & $\geq 0,6$ & $\geq 0,8$ & $\geq 1,0$ & $\geq 1,3$ & $\geq 1,7$ & $\geq 2,1$ & $\geq 2,5$ & $\geq 3,5$ \\
\hline
\end{tabular}




\subsection{Test results}

The experimental tests were carried out on a test track of the Safety System Research Institute in Inowrocław in cooperation with a team from the Road and Bridge Research Institute. Fig. 5 presents a view of a car located in the test area before the commencement of the test.

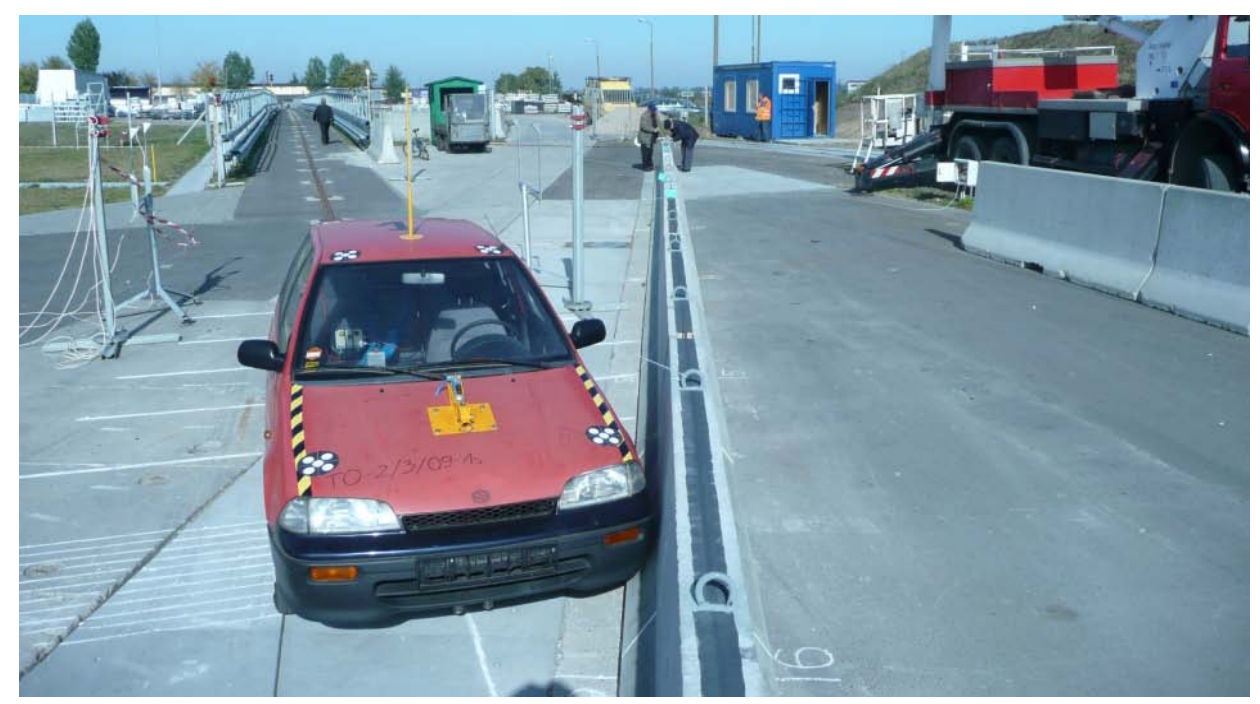

Fig. 5 Test area

On Fig. 6 selected phases of vehicle motion obtained from the experimental and simulation tests were compared. Safety barrier system displacements and a vehicle motion track show high consistency. It indicates that simulation methods are useful in that type of testing.

Fig. 7 presents a view of the car after the test completion. The car was smoothly led out from the impact zone and braked using a remote-controlled braking system when it left the acceptable reflection area. At the final stage the car was taken over by a gravel protective embankment. Such vehicle braking method is necessary due to a risk of unacceptable secondary damage not related to a barrier contact. The front part of the body was slightly damaged but there was no significant passenger compartment deformation. After the test all car doors could be open without bigger problems. Measurements of characteristic car dimensions made after the crash test did not show any significant changes compared to the initial dimensions. 


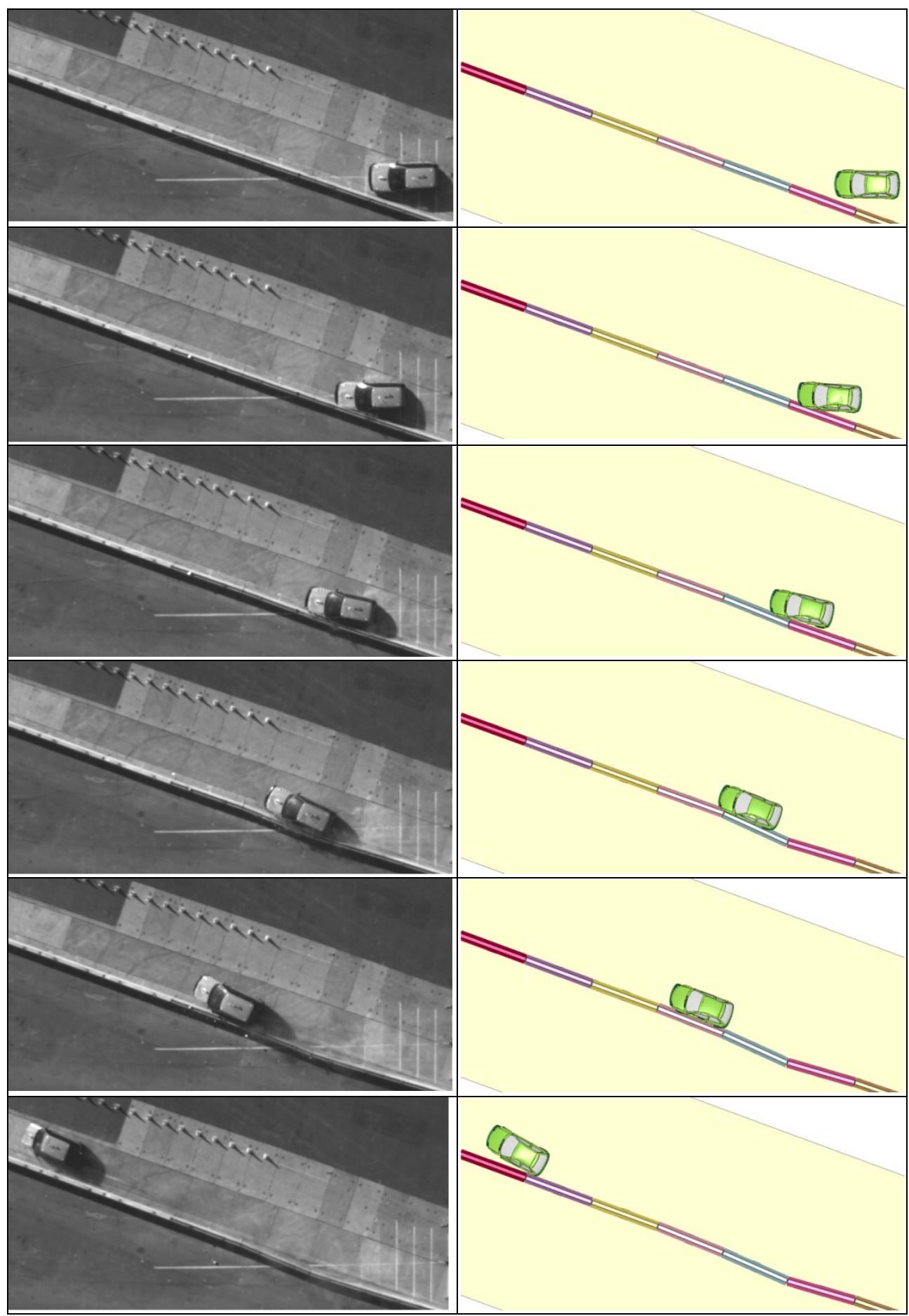

Fig. 6 Phases of vehicle impact with a concrete barrier 


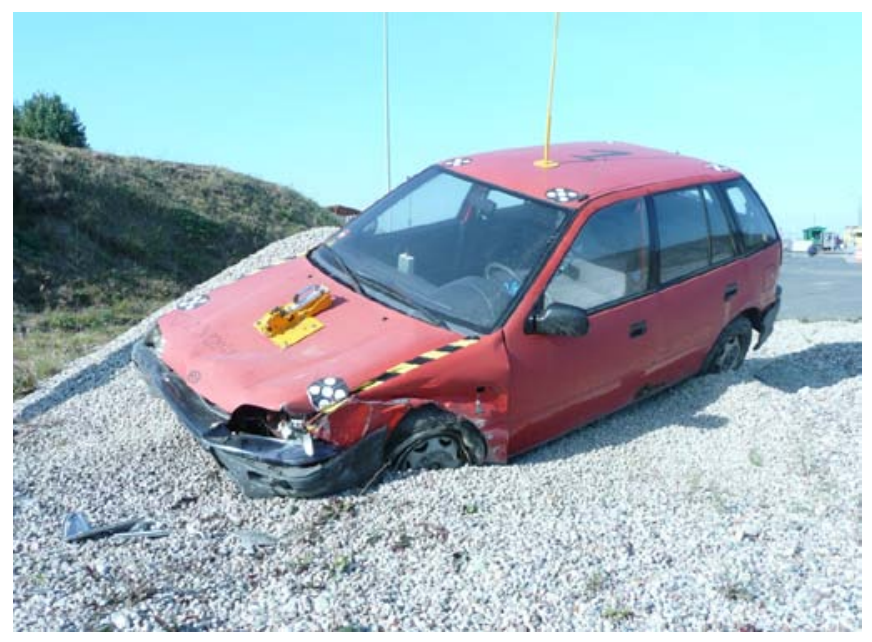

Fig. 7 Effects of the car impact with the barrier

Fig. 8 presents the concrete barrier system after the impact. The segment where the point of impact was located underwent the biggest displacement. Dynamic deflection for that segment amounted to $27 \mathrm{~cm}$. Moreover, the barrier system was not broken during the impact. The photo shows the reflection area marked by the road posts placed parallel to the barrier axis. This area was not disturbed in any location.

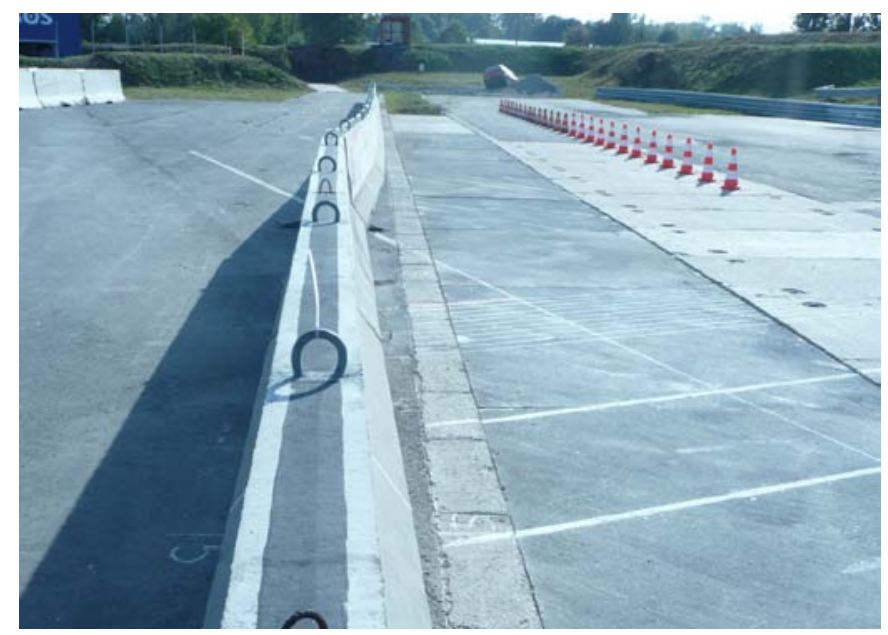

Fig. 8 Barrier displacement

Table 3 compares selected safety barrier parameters and evaluation factors obtained as a result of the experimental and simulation tests. They allow to evaluate the quality of obtained results. The biggest differences can be seen for dynamic deformation. It is probably caused by improper (underrated) 
selection of segment ground friction factor and it resulted in higher barrier displacement in the simulation tests. It can be also justified by the maximum acceleration values and ASI index calculated based on it.

Table 3. Comparison of parameters and indexes of simulation and experimental tests

\begin{tabular}{|l|c|c|c|}
\hline \multicolumn{1}{|c|}{ Parametr } & $\begin{array}{c}\text { Simulation tests } \\
\text { results }\end{array}$ & $\begin{array}{c}\text { Experimental tests } \\
\text { results }\end{array}$ & $\begin{array}{c}\text { Difference } \\
{[\%]}\end{array}$ \\
\hline Vehicle speed $[\mathrm{km} / \mathrm{h}]$ & 100 & 102 & 2,0 \\
\hline Impact angle $\left[{ }^{\circ}\right]$ & 20 & 20,66 & 3,2 \\
\hline Dynamic deflection $[\mathrm{m}]$ & 0,33 & 0,27 & 22,2 \\
\hline Working width [m] & 0,88 & 0,82 & 7,3 \\
\hline $\begin{array}{l}\text { Acceleration severity } \\
\text { index ASI }\end{array}$ & 1,30 & 1,58 & 17,7 \\
\hline $\begin{array}{l}\text { Maximum longitudinal } \\
\text { accelerations }\left[\mathrm{m} / \mathrm{s}^{2}\right]\end{array}$ & 9,5 & 10,9 & 12,8 \\
\hline
\end{tabular}

\section{Conclusions}

The work presents the issue of road restraint system testing. Due to a need to provide road traffic safety, an independent confirmation of operation efficiency is required for each new introduced solution. The existing testing and evaluation system, by introducing defined combinations of crash tests for individual restraint levels, is oriented towards providing protection for all possible participants of the road accidents.

The work presents the results of simulation and experimental crash tests involving a $900 \mathrm{~kg}$ car and the concrete barrier system (TB11 test). This is the most common test applied both to low and high restraint systems. The tests and evaluation were carried out according to the requirements defined in EN 1317-2 standard. Obtained results can be characterized with high qualitative and quantitative consistency as far as the barrier displacement, car behavior and car deformation are concerned. It proves that simulation methods can be useful in the protective system testing, particularly at the stage of design and defining structural solution variants.

\section{References}

1. PN-EN 1317-1: 2001 Systemy ograniczające drogę - Część 1: Terminologia i ogólne kryteria metod badań.

2. PN-EN 1317-2: 2001 Systemy ograniczające drogę - Klasy działania, kryteria przyjęcia badań zderzeniowych i metody badań barier ochronnych. 
3. PN-EN 1317- 3: 2003 Systemy ograniczające drogę. Część 3: Klasy działania, kryteria przyjęcia badań zderzeniowych i metody badań poduszek zderzeniowych.

4. PN-EN 1317-5 + A1:2009 Systemy ograniczające drogę. Część 5: Wymagania w odniesieniu do wyrobów i ocena zgodności dotycząca systemów powstrzymujących pojazd.

5. PN-ISO 6487:2005 Pojazdy drogowe. Techniki pomiarowe w testach zderzeniowych.

6. http://www.ncac.gwu.edu/

7. LS-DYNA Keyword User's Manual Version 971, Livermore Software Technology Corporation (LSTC). Livermore, 2009.

The scientific work financed by the funds assigned for the science during 2007-2010 as a developing project.

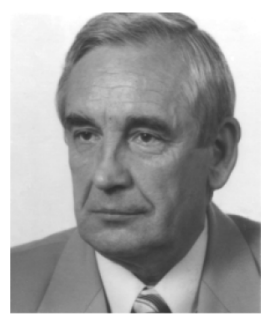

Waclaw Borkowski Prof. DSc. Eng. Professor at Military University of Technology, Faculty of Mechanics in Warsaw, Poland. Specialization: mechanical engineering, simulation and experimental testing of vehicle dynamics and road traffic safety.

Membership in many scientific committees of conferences and congresses.

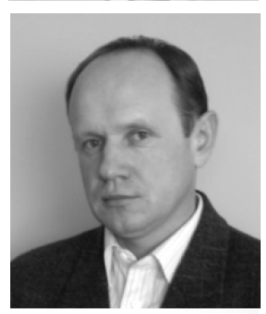

Zdzisław Hryciów PhD. Eng. Works at Military University of Technology, Faculty of Mechanics in Warsaw, Poland. Specialization: mechanical engineering, simulation and experimental testing of vehicle dynamics and suspension optimization.

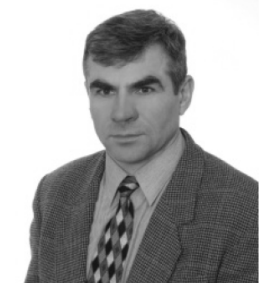

Piotr Rybak PhD. Eng. Works at Military University of Technology, Faculty of Mechanics in Warsaw, Poland. Specialization: mechanical engineering, simulation and experimental testing of combat vehicle dynamics loads in the aspect of operation safety, testing of protective structures of military vehicle.

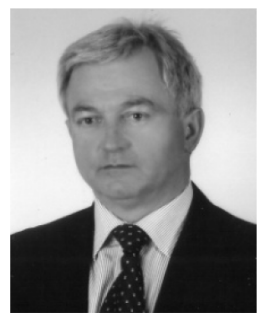

Józef Wysocki PhD. Eng. Works at Military University of Technology, Faculty of Mechanics in Warsaw, Poland. Specialization: mechanical engineering, vehicle dynamics, road traffic safety, simulation and experimental testing of vehicle suspension elements. 